\title{
UNIVERSITYOF
}

FORWARD

THINKING

WESTMINSTER用

WestminsterResearch

http://www.westminster.ac.uk/westminsterresearch

Extended urbanization in small and medium-sized cities: the case of Cirebon Indonesia

Fahmi Fikri, Z., Hudalah, D., Rahayu, P. and Woltjer, J.

NOTICE: this is the authors' version of a work that was accepted for publication in Habitat International. Changes resulting from the publishing process, such as peer review, editing, corrections, structural formatting, and other quality control mechanisms may not be reflected in this document. Changes may have been made to this work since it was submitted for publication. A definitive version was subsequently published in Habitat International, 42, 1-10.

Habitat International is available online at:

https://dx.doi.org/10.1016/j.habitatint.2013.10.003

(C) 2014. This manuscript version is made available under the CC-BY-NC-ND 4.0 license http://creativecommons.org/licenses/by-nc-nd/4.0/

The WestminsterResearch online digital archive at the University of Westminster aims to make the research output of the University available to a wider audience. Copyright and Moral Rights remain with the authors and/or copyright owners.

Whilst further distribution of specific materials from within this archive is forbidden, you may freely distribute the URL of WestminsterResearch: ((http://westminsterresearch.wmin.ac.uk/)).

In case of abuse or copyright appearing without permission e-mail repository@westminster.ac.uk 


\section{EXTENDED URBANIZATION IN SMALL AND MEDIUM-SIZED CITIES: THE CASE OF CIREBON, INDONESIA}

Abstract. Although urbanization in smaller cities is arguably not imperative, the future of urban living is no longer expected to be principally in mega-cities. People increasingly live in intermediate and smaller cities, in line with the proportion of people residing in urban areas, which is also gradually rising. Smaller cities in Indonesia, like other smaller cities in the developing world, are relatively densely populated, and many of them are experiencing extended urbanization, thereby exceeding their administrative boundaries. This paper seeks to explore the factors triggering urban development in these smaller cities. Urban change in Cirebon Region has accelerated since the late 2000s, very much in line with the decentralization policy in Indonesia. This paper shows that urban change is mostly influenced by economic restructuring, which encourages people to live closer to the core of the region, representing a new link between the core and new emerging urban areas in the region.

Keywords: extended urbanization, triggers, economic restructuring, smaller cities, Indonesia

\section{INTRODUCTION}

Over the last decades, urban studies have paid overwhelming attention to the characteristics and problems of urban development in mega-cities and metropolitan regions. Mega-cities generally represent significant contributions to the national economy and can act as gateways to the wider globalized world. Urban systems in developing countries are mostly typified by primacy, as shown by central place theories (Cohen, 2004, 2006). There are many examples of this, such as Jakarta (Indonesia), Mexico City (Mexico), Seoul (South Korea), Bangkok (Thailand) and Budapest (Hungary). Primate cities often perform as capital cities, in addition to frequently functioning as the engines of economic growth. 'Favouritism'-the phenomenon where people tend to prefer to 
concentrate in certain areas-is similar. Such cities can be preferred as places to live due to the amenities they provide and the job opportunities they offer. It is therefore unsurprising that larger cities tend to be the most commonly studied: these cities are generally considered to have a great influence on the economic and political stability of nations.

At the same time, small cities-as Bell and Jayne (2009) criticized-as parts of larger global city-regions, too, are studied less often and are under-theorized. However, the urban system is more heterogeneous; it not only consists of large cities. Secondary and tertiary cities also potentially play important roles, for instance, as specialists for certain products or commodities, as capital cities or as distribution centres. According to the United Nations (2012), 52.1\% of the world population live in urban areas, of which only approximately $17.7 \%$ are in large and mega-cities: the rest of the urban population mostly inhabits smaller urban agglomerations. Therefore, this paper argues that researching the characteristics of urbanization in smaller cities is important.

Several arguments can be assembled as a conceptual foundation. Firstly, as Rondinelli (1983) argued, the role of small cities and towns is to stimulate rural development and to integrate urban and rural economies. He also pointed out that small cities could specifically contribute to a diffusion-ofinnovation process from metropolitan regions and to specialization in certain functions or sectors. Secondly, according to Cohen (2006), it is important to consider urbanization in small cities as, recently, current population rates of smaller cities have become demographically significant. The urban future, he argued, would occur mostly in smaller and medium-sized cities, where the bulk of the urban population also resides. Moreover, smaller cities in developing countries seem to have different characteristics from those in the developed world. As indicated by Cohen (2006), urban growth in developing countries is more rapid, and the smaller cities under discussion typically grow faster than larger cities (cf. Zhou, 1991). He mentioned that there are advantages to being small, in the sense that such cities still have time to accommodate basic infrastructure and service gaps before the service gaps become too large. In another piece of work, Dix (1986) strengthen the argument that smaller cities have an advantage in developing a sense of (place) identity, and this advantage could not be enjoyed if the rate of development, and urbanization, is too fast. This indicates that attention should be paid to the implications of extensive urban changes on governance and planning issues. 
In Indonesia, according to the 2010 Population Census (in Firman, 2012), 118.3 million people, or $49.7 \%$ of the total population, live in urban areas. The bulk of the urban population, 80.5 million of 118 million (68\%), are clustered on Java Island, while the remainder is spread across the other islands. Cirebon is an example of a smaller city on Java: it is densely populated and urbanizing. ${ }^{1}$ Growth and development of its urban areas has grown, relatively enlarged. Cirebon Region comprises the Cirebon Municipality (kota) and the Cirebon District (kabupaten). ${ }^{2}$ The Cirebon Municipality is considered a small city with only 300,000 inhabitants. There are an additional 400,000 people in the outer urban agglomeration, administratively known as the Cirebon District. Overall, this extended urban area represents a smaller city-region. ${ }^{3}$

This paper sets out to clarify the driving forces (triggers) behind urban challenges such as extended urban development in smaller cities. Various external triggers could be influential, including foreign investment and devolvement effects resulting from Indonesian decentralization policy, which could have encouraged local governments to more actively promote their regions and fiscally encourage local urban development. Extended urbanization could also be triggered by internal processes within the region, either demographic, economic or political. The case of Cirebon, an urban region in decentralised Indonesia, is central to the analysis. Cirebon is particularly suitable given its growth and extended urban areas, which stretch beyond the administrative boundary of the Municipality. A lack of basic services and infrastructure provision, and the institutional capacity to deal with them, is also present. This case, is therefore likely to be representative and should establish an improved understanding of rapidly urbanizing secondary and tertiary cities in Indonesia, and perhaps decentralized developing countries in general. It may also deliver policy advice on specific drivers of urbanization in smaller cities, and how to address these drivers and manage change in the future.

The remainder of this paper is structured as follows. The second section discusses theoretical perspectives on urbanization and development in the context of small cities. Theories and previous studies on the drivers of urbanization are also presented in this part, and the latter part briefly explains the methodology. Section four describes the patterns of urbanization in Cirebon Region, while section five presents the overall analysis, comprising of the demographic, economic, physical and policy 
changes that have triggered urban development in Cirebon Region. Finally, the last part sums up the discussion and suggests policy implications for the future of urbanization in Indonesia.

\section{URBANIZATION AND SMALL CITY DEVELOPMENT}

As small cities are not often mentioned in discussions of urbanization, this section attempts to assemble the concepts and theories related to urbanization that fit the context of smaller cities in developing countries. In this literature review, the main emphasis is on urbanization drivers.

A fundamental issue, of course, is the definition of 'small cities' itself. The most basic definition is essentially based on population size. For example, the United Nations (2012) defines small cities as urban agglomerations with populations of less than 500,000. Nevertheless, Bell and Jayne (2006) have argued that it can be problematic to define small cities only by population size, because urban hierarchies differ greatly across the world. It would be preferable to define them based on their smallness, third-tierness, localness or, in other words, their function within regions.

Although there has been renewed interest and vivid recent debate on the role of small cities and towns in regional development, explanations of urbanization processes and characteristics in small cities have remained less obvious and inconclusive. Topics covered in existing publications mainly emphasize the role of small towns within regional development, such as a long-term study by Hinderink and Titus $(1988,2002)$. An important relevant conclusion from their research is that the role of small cities is often bypassed by national policy and global market mechanisms. Ultimately, small cities frequently fail to undertake action such as diffusing innovation to rural areas or specializing in certain products or functions. However, an important conclusion from this literature is that the factors of economic restructuring, planning and political processes could trigger urban development in smaller cities.

Another important acknowledgement in the literature is that the characteristics of American and European small cities are different from those in developing countries, which are relatively more densely populated and grow faster than large cities (Cohen, 2006). A framework, therefore, for examining smaller cities in the context of developing countries will need to consider facts and studies 
beyond the developed world. In this debate, several theories of urbanization in the metropolitan context, or at least extended urbanization in the context of developing countries, are also considered.

One influential work is Terry McGee's model of the extended metropolis (1991). In this model, the spatial configuration of Asian countries consists of (a) major cities which are usually extremely large cities; (b) peri-urban regions, which are those surrounding the cities within a day's commute; (c) desakota regions, which are an intense mixture of agricultural and non-agricultural activities that often span corridors between large city cores; (d) densely populated rural regions; and (e) sparsely populated frontier regions. However, transferring this concept into the context of small city-regions does not seem that helpful. As Webster (2011) indicated, defining peri-urbanization in smaller cities is problematic; in fact, the core of smaller regions is relatively small, likewise the commuting distance is much shorter. Moreover, the rural region characteristics remain strong in smaller cities: the region is undergoing a transition from rural to urban.

Accordingly, it seems that the best way to examine small city characteristics in Indonesia remains the basic concept of urbanization. Although McGee mentioned 'small and intermediate cities' in his model, he actually meant smaller cities with different contexts to those under discussion in this paper. As Prabatmodjo (1993) pointed out, small cities can be classified into two types: those in the context of mega urban regions and those within rural regions. This paper refers to the second context with regard to concerns about the transition from rural to urban.

A final consideration on urbanization is reflected by the work of Geyer (1993), who offered the concept of differential urbanization in medium-sized and small cities. A defining idea is that urbanization in intermediate and small cities is influenced by primate city development. Counterurbanization in large cities is followed by concentration in intermediate cities. In the same sense, deconcentration in intermediate cities at a later stage is followed by concentration in small cities. Hence, urbanization in small cities is a consequence and impact of urbanization in large cities.

\section{Drivers of urbanization}


Despite Geyer's model, which employs migration data to determine the effects of large cities on urbanization in small cities, this model remains insufficient to describe what drives urbanization in smaller cities. Scholars have discovered several factors that could induce urbanization. Cohen (2006) has argued that urbanization and city growth is caused by diverse reasons related to rural-urban migration, natural population increase and annexation. In addition, Erickcek and McKinney (2006) have explained that the growth of a metropolitan area depends on its economic structure, human capital resources, quality of life factors, historical trends and location.

Although little discussion can be found on urbanization triggers in smaller cities, several results from previous research should be mentioned here. A study by Han (2010) has explained that smallcity urban expansion in contemporary China is an outcome of multiple processes, including economic restructuring and increases in income and population which generate increased demand for land and new building space, planning preparation, profit-seeking practices and, more importantly, efforts by local governments to achieve economic ambitions.

Meanwhile, Webster (2011) has pointed out that the drivers of change in peri-urban areas include industrial and non-industrial drivers. He emphasized that in defining those drivers, two forces must be considered: centripetal (inward driving) and centrifugal (outward driving) forces within an extended urban region. Centrifugal forces in many middle-income countries can include manufacturing investment, rapid development of expressways and the urban land market, in which land price is lower at the periphery. Cultural preferences also play a role in the sense that people with high incomes may wish to live in peripheral areas, as found in North America and Australia, despite housing projects being offered close to the core. Meanwhile, centripetal forces have been found to probably be related to economic structural changes that encourage urbanization. This could involve certain sectors, for example services, which tend to concentrate spatially in specific areas. However, cultural factors and choice limitation can also play a role in the same way as centrifugal forces.

In addition, as Goldblum and Wong (2000) found when examining the origins of urban expansion in Jakarta, speculative activities can also be considered as a factor of urban change. In the Jakarta context, land price in the central area is largely controlled by international capital, while in Cirebon Region, foreign direct investment is not widespread. However, this only shows that in land 
development, spatial change can also be instigated by parties with the economic power to dominate the land market.

\section{ANALYTICAL FRAMEWORK}

This study employs a political economy perspective ${ }^{4}$ to capture who (actors) or what (factors) triggers urban change. This perspective captures the roles of and relationships between actors in the process of urban and built environment creation. In a sense, we could just determine all the actors related to urban land development (cf. Pacione, 2009), including building firms, subcontractors, architects, marketing agents, developers and speculators, and legal and financial consultants. However, this study not only attempts to describe what the triggers are, but also how they interact within the urban system. This presents two possibilities: whether change is more readily triggered by external factors such as spread effects, decentralization or deconcentration from larger urban centres; or whether this merely reflects the position of the Cirebon Municipality as an engine of growth in Cirebon Region.

Webster (2011) argued that within spatially extended urban areas, dramatic changes in land use, built environment, economic structure, environmental status and social constructs can be understood by examining the landscape outcomes of industrial and non-industrial drivers of urbanization. Therefore, to deliver a better international insight into the drivers of urbanization, this paper analyses land use changes within the region in question, along with an examination of other aspects. As also indicated by the literature, factors causing urban development include demographic change, economic change, planning preparation and political process. Nevertheless, these factors basically attempt to explain the development of changes. Consequently, this paper examines land use changes from the standpoint of the physical evolvement of the built-up area. In demonstrating how the built-up area expands over time, a series of maps (1994, 1997, 2001, 2005 and 2009) have been analysed, complemented by supporting data. Operationally, the main analysis includes settlement development, trends and growth, and underlying related processes.

Secondary data was also gathered from the Central Statistics Agency. Demographic data including urban population and its growth - and economic data including gross domestic product and 
labour force - represented in location quotient - was employed to support the descriptive analysis. Shift-share analysis was also performed to show more clearly how economic restructuring takes place. A series of interviews were conducted to obtain diverse points of view on existing problems, local preferences and policy issues in the region with actors from local government in the Municipality and the Cirebon District. Meanwhile, to explain the external factors and policy issues, policy and planning documents were also prepared and analysed. In the end, all the aspects of analysis were recorded in a map to show the direction of urban development and to exemplify all the possible drivers of urbanization (see Figure 5).

\section{URBANIZATION PATTERNS IN CIREBON REGION}

Cirebon is located on the north-eastern coast of West Java province, approximately $300 \mathrm{~km}$ northwest of Jakarta, the capital city of Indonesia, and about $200 \mathrm{~km}$ northeast of Bandung, the capital city of the province. Cirebon is transected by the Pantura (Java Northern Coast) line, which is one of the important national transport corridors on Java Island. According to Law 26 (2007) on Spatial Planning, the Cirebon Municipality, which has 230,504 inhabitants, can be classified as an intermediate city. However, defined relative to its position and functions, it can also be classified as a

small city. ${ }^{5}$ Jakarta is the primate city and other metropolises such as Surabaya, Bandung and Medan, while sufficiently large, are classified as intermediate cities. It is clear therefore that Cirebon is small in comparison.

As a small city-region, Cirebon is well known for several things that represent its local and cultural economic identity. The city is known for its shrimp, which makes it popular as 'the city of shrimp' (kota udang). It is also famous for its high quality batik from Trusmi. As already mentioned, this region consists of two administrative regions, including the Municipality and the Cirebon District. In fact, in the past, this region was a part of Karasidenan Cirebon: in 1959 the urban area became a new Municipality. Accordingly, the formation of this Municipality has nothing to do with the effects of Indonesian decentralization policy (pemekaran daerah) in 1999. 
In the national spatial plan (2008) and the provincial spatial plan (2010), Cirebon is designated as a regional activity centre (pusat kegiatan wilayah) which also serves the surrounding Districts, which in the past were known as Karasidenan Cirebon, including Majalengka, Kuningan and Indramayu. Several smaller centres are also recognized within the Cirebon District in these plans. Sumber is the district capital and the second-level centre (urban centre of the District). Meanwhile, Arjawinangun, Palimanan, Lemahabang and Ciledug subdistricts are prearranged as rural centres and third-level centres. In addition, according to the provincial policy (2010), Cirebon Region is now recognized as a 'metropolitan' region. This should not be taken literally, but reflects an expanded function for the Cirebon economy, as well as the extended urbanization in the region. The pattern of urban development in Cirebon Region can thus be indicated either by urban population increase or by the expansion of the built environment.

\section{Urban population increase}

According to demographic data, population growth in the Municipality is an undramatic $2 \%$ per year. However, the Statistical Bureau found an interesting population increase from 310,000 at the end of 2009 to 313,692 in March 2010. The Department of Population and Civil Registration in the Municipality argued that this rapid population increase corresponds to a high birth rate and inmigration level (Kompas, 2010). However, another local board, responsible for family planning (keluarga berencana) (in ANTARA, 2010), ${ }^{6}$ showed that the total fertility rate (TFR) in the Municipality in 2010 was only 1.7 , which was much lower than the national average (2.7). The previous statement cannot therefore be proved. Meanwhile, checking the in-migration level is quite challenging because the availability of data on migration in Indonesia has been problematic, and it is thus difficult to visualize how much migration takes place in the Municipality.

Table 1. Shares of urban agglomeration in Cirebon Region, 1990-2006 


\section{AROUND HERE}

Source: Adapted from Central Statistics Agency (1990, 2000, 2006)

It is not enough to explain demographic changes only in the Municipality, because in this case the main urbanizing part is the agglomeration area close to the Municipality under the territoriality of the Cirebon District. In Table 1, the urban population across each part of the agglomeration is presented as respective shares of urban population across a series of years. The shares of urban population in the core tend to decrease over time, whereas the population has increased slightly. The most rapid increase in the shares is in the urban agglomerations adjacent to the core (17.7\% in 2009), where most new settlement developments are located. During the period 2000-2006, the population in that area almost doubled. A possible explanation for this, also in relation to the in-migration issue mentioned in the previous paragraph, is that this valued increase corresponds to massive migration by people who previously lived in places far from the core. An observation that could be argued to support this statement is the population decrease in the scattered urban agglomeration across Cirebon District during the same period (see row 5 in Table 1).

\section{Physical expansion}

The progress of urbanization can be observed more clearly from physical changes. A series of built-up area maps from the National Coordinating Agency for Surveys and Mapping were analyzed and overlaid, so that the evolution of urbanized areas could be clearly seen during the period 19942009. Figure 1 represents the map analysis. During the 1990s, there was essentially no urban expansion around the agglomeration adjacent to the core. Built-up areas throughout the embankment zone (alongside the core to Kapetakan) clearly already existed before or since the early 1990s. Development in this area was triggered by fishery activities and is generally associated with informal settlement. The fishing communities prefer to live there, given the ready access to the Cirebon Municipality, where they distribute their produce. 
Since 2001, the growing patterns of urban development are generally more extensive. However, until 2005, only Mundu had a significant development, which was a housing development project for low income people. A massive and accelerated development trend emerged in the period between 2005 and 2009. This trend included agglomeration growth in and around the core, forming a concentric pattern and stripping corridors (urban development along roads) to Jakarta and Bandung. Sumber, the capital of Cirebon District, was increasingly connected to the core. This extended development reveals new core-periphery relationships or relationships between activity centres: between the core (Municipality) and peripheral centres in the Cirebon District, in which each centre has its own functions and position.

The above explanation shows that urbanization in this smaller city-region follows different patterns from the other metropolis cases. As McGee (1991) argued, urban development patterns in Indonesia are widely described as a mixture of agricultural and non-agricultural activities alongside highways: that is, desakota phenomena. Although this kind of ribbon development is still found in Cirebon, the extended urban agglomeration around the core demonstrates that urban development does not always follow main roads. Moreover, while in Jakarta, urban deconcentration is likely, in smaller cities like Cirebon, urbanization seems to concentrate toward the core.

Figure 1. Physical expansion in Cirebon Region 1994-2009

\author{
FIG1.jpg \\ AROUND HERE
}

Source: Analyzed from National Coordinating Agency for Surveys and Mapping (1994, 1997, 2001, 2005, 2009) 


\section{LOOKING FOR TRIGGERS OF URBAN CHANGE IN CIREBON REGION}

After describing the general pattern of urban development in Cirebon Region, this section seeks to elaborate all the factors triggering urbanization in the region. As previously indicated, the rapid urban change that is habitually shown through urban population increase and the physical expansion in the outer agglomeration of the Municipality contains properties of both internal and external triggers. Several aspects are considered in the analysis, including demographic changes, economic restructuring, settlement development, the relationship with larger metropolises, and political and planning processes.

\section{Economic restructuring}

No large-scale changes in shares of gross regional domestic product (GRDP) were observed, as can be seen in Figure 2 and Figure 3. Industry and the commercial sector have become increasingly dominant in the Municipality. These activities, including shopping malls, tend to attract people even from beyond Cirebon Region. The agricultural sector in the District appears to have declined since 2000. Fishery activities, which caused Cirebon to be known as 'the city of shrimp', have also decreased. Today, embankments related to fishing in the area of Kapetakan have gradually closed, in line with a decline in shrimp production.

Figure 2. Percentages of GRDP in the Cirebon District 1995-2005

FIG2.docx

AROUND HERE

Source: Adapted from Central Statistics Agency (1999, 2008) 
Figure 3. Percentages of GRDP in the Cirebon Municipality 1995-2005

FIG3.docx

AROUND HERE

Source: Adapted from Central Statistics Agency (1996, 2001, 2004)

Compared to the location quotients ${ }^{7}$, which show how concentrated the economic sectors in the region are compared to the national average (see Table 2), we found that the agricultural sector seems to be less dominant than manufacturing and services sectors in both the District and the Municipality, with a significant decrease in the District. In the Municipality, the services, finance and trade sectors currently perform as economic bases, as does the construction sector in the District. The construction sector in the Municipality has become less dominant, while in the District it has slightly increased. This means that construction is now more intensive outside the core. It is also interesting that in the District, the trade and services sectors have now become more important, displacing manufacturing and transportation. This indicates that economic restructuring is occurring in the District as a result of economic changes in the Municipality and as a response to the decline in several sectors which were previously economic bases in the District. In addition, unusually strong location quotients were found for the electricity, gas and water sectors in the Municipality for both years. This substantial change can be explained by the relatively higher proportion of people working in that sector given the smaller size of the Cirebon Municipality. Employment in the sector in the Municipality is growing more rapidly than the national employment share in that sector, which is broadly constant $(0.5 \%$ growth per year).

Table 2. Location Quotients for the District and the Municipality in 1992 and 2007

TAB2.docx 


\section{AROUND HERE}

\section{Source: Calculated from Central Statistics Agency (1992a, 1992b, 2009a, 2009b)}

Data on investment and industrial activities are not available through the Central Statistics Agency. Our review suggests, however, that these activities are minor compared to Jakarta or other larger cities in Indonesia. Industrial activities in this region are mostly characterized by home and small industries, particularly batik (dyed textiles) and rattan (furniture made from palm stems). There is no evidence of considerable foreign direct investment in this region; there are no industrial complexes and plants, except for the cement industry in Palimanan.

The rattan industry has represented unique challenges for the Cirebon economy. Cirebon was one of the largest suppliers of rattan products during the 1990s: these home industries have now gradually declined. The decline corresponds to the national export policy in 1999, which allowed massive exports of raw rattans. In that period, a number of home industries went bankrupt until, in 2004, the policy was ended (Ministry of Trade, 2011). Even though the government has now terminated this export policy, rattan industries in Cirebon still struggle to survive. A key reason is that the development of rattan industries in Cirebon Region is no longer prioritized in the new policy of the Ministry of Trade (ANTARA, 2012b). Therefore, it can be argued that the development of this sector does not correspond to the current urban changes in Cirebon Region.

The decline in both agricultural and manufacturing sectors indicates a shift in the regional economy of Cirebon. Economic restructuring in the Cirebon District, however, at least indicates two possibilities. First, local economic development in the District could be currently taking a new path towards a more advanced economy. Alternatively, it is possible that the amount of employment in the District does not reflect the local economy itself, because people who work in the Municipality commonly live and reside in the District. As a result, the District's economic base cannot be interpreted literally. The regional economy of the Municipality and the District is a unity and cannot be separated. 
Figure 4. Developments in the number of projects and their area (ha) in Cirebon Region

FIG4.docx

AROUND HERE

Source: Adapted from Real Estat Indonesia West Java (2012)

Note: Numbers inside the brackets indicate the number of projects

\section{Settlement development}

As previously suggested, the Municipality - as this region's core - also acts as a centre for economic activities, but only for trade and services. However, these sectors offer a large number of jobs which cannot only be filled by people from the Municipality. People have attempted to locate closer to the core and seek affordable housing, but in fact, the core lacks land and land there is expensive. Land prices in the Municipality reached $100-175$ thousand rupiahs per $\mathrm{m}^{2}$, while remaining at only $40-60$ thousand rupiahs in the District. Therefore, people look further afield in their search for cheaper land and houses, not necessary in the core, but particularly in adjacent areas with easy access to the core. Concomitantly, developers seek opportunities in the housing markets by meeting people's needs to live beyond the core.

Settlement development has been found as the main cause of physical changes in Cirebon Region. The property business seems to be much in demand among investors, both from Cirebon and other cities. The number of new housing development companies has gradually increased since 2007, rising from two developers in 2007, to 16 in 2008, 29 in 2009, 58 in 2010 and 32 in 2011 (Cirebon Pos Kota, 2011). The projects undertaken by these developers are presented in Figure 4. There is an evident fluctuation over time. The trend from 1996 to 1997 is upward, followed by a downturn during 
the Asian monetary crisis in 1998-1999. Afterwards, property development revived again. Recently, houses have been built on a demand basis and generally on a small scale, for instance only 100 houses within no more than five hectares of land.

Table 3. Examples of large housing development projects in Cirebon Region 2007-2012

TAB3.docx

AROUND HERE

Source: Real Estat Indonesia West Java (2012)

Even though housing development seems essential to explaining urban changes in Cirebon Region, the scale of projects tends to not be as low, and indeed, not comparable with larger metropolitan regions like Jakarta (see Table 3). In practice, housing development across the region has also been a result of communication in the land market. Developers have attempted to enter the land market in the Municipality, attracting some people's interest, especially the middle-income class. However, this has not always been successful, because houses on expensive land are often not affordable. The preferred areas for development are located in the District, yet close to the core, as people prefer these locations with better accessibility. Although new housing has been developed east of the core, including in Mundu and Astanajapura, people have preferred to live in places such as Kedawung, Weru and Plumbon because these areas are closer to the core, have better accessibility and, importantly, better basic infrastructure services. In addition, people also prefer areas around Sumber, which is the new capital of the Cirebon District, and a traffic corridor towards central Java.

As a result, the general pattern of residential location can be characterized as follows. Higherincome people reside mostly in the Municipality and the subdistrict of Kedawung, while middle and lower income people live in places like Weru, Plumbon and Sumber. Housing in the eastern region, in 
places such as Mundu and Astanajapura, is inhabited by low income people (see Figure 5). Additionally, this also includes a number of failed housing development projects in remote areas which are really not accessible from the core.

Speculative practices are indicated as present in the housing and land markets. Our review suggests that there are several cases where people have purchased houses they do not actually live in: these purchases are for future investment purposes only. Property consumers, $40 \%$ of whom are from outside Cirebon Region, are also an indication. These consumers are typically commercial parties from Jakarta, who have opened branches in Cirebon (Kompas, 2008). In addition, although developers seek to acquire profitable land, it seems that they tend to be careful in building new housing projects. According to interviews, developers in the region prefer demand-driven housing development, especially for low-income houses. Prospective consumers are expected to pay an advance before their houses are built; alternatively, they face preliminary assessment by the creditor banks.

However, formal housing development cannot capture the whole picture because informal settlement is also widespread. There are no exact data explaining this phenomenon, but informal housing arguably accelerates the extensive development of urban agglomerations. This can be found in several locations, especially along the road corridors to Jakarta and Bandung.

\section{Policy and political process}

In this section, we explore whether development policies and spatial plans correspond to urban changes in the region. It has been well established that government policies and national political institutions affect the degree of urban concentration (cf. Davis \& Henderson, 2003). That is also probably true for the problem of imbalance in growth and development between eastern and western Cirebon Region. As activities and people concentrate in the west, also for the well-developed infrastructure, the east seems to be being left behind. Although the district government has long desired to develop the east as an industrial complex for large manufacturing activities through policy strategies, this has not become a reality. Foreign direct investment and the development of large industrial activities deliver externalities at the national level, so these matters have to be regulated by 
national policy. So far, there has been no sign that investment will be made in Cirebon for any kind of industrial sector. It appears true that national policies and institutions influence urban concentration in the region, but at the same time this influence emerges from essentially 'doing nothing'. Once the national government succeeds in creating opportunity for developing new industrial parks in eastern Cirebon, the story may change.

In Indonesia, urban reality is typically the result of market mechanisms, while the so-called 'plan' does not have a significant role; indeed, it only follows growth and current trends, and does not create new spatial patterns. Moreover, as implied from several interviews with local government actors, the Municipality and District spatial plans have not been synchronized. Extended urbanization in the agglomerations adjacent to the core is viewed differently by the Municipality and the District governments. The Municipality regards this as a burden, especially in infrastructure and facilities provision, while the District presumes this is a 'trickle-down effect' as the Municipality does not have the capacity to carry on urban development. This difference is reflected in the interview results:

'... Urban development in Cirebon has extended because the Municipality lacks land to carry out activities. As hinterland, the Cirebon District only receives trickle-down effects from the Municipality.' (Interviewee from the District)

'... The development in the subdistricts in the border area of the District is a burden to some extent for us the Municipality, especially in providing infrastructure and basic services, because the people who live there want to get services from us, but it is not possible due to territoriality issues...' (Interviewee from the Municipality)

This corresponds to Indonesian decentralization, where local governments have greater authority in managing their territories. Building permits can be issued widely for the development of new housing and commercial areas, particularly because of the possibility of higher tax revenues.

The preceding statement can be elaborated generally through the Indonesian planning system. The country adopts a regulatory system in which, de jure, spatial plans determine permitted land use zoning. In practice, development processes indicate a more discretionary system, in which any activities and uses of land can be proposed and compromised. This could be the bottleneck for many urban planning problems in Indonesia. In the Cirebon case, Municipality and District spatial plans are 
actually available, but developers only have to follow an approval mechanism in executing housing projects. According to interviews, the process can be described as follows: firstly, developers arrange the 'fatwa permit', ${ }^{8}$ which is the recommendation or approval from the Local Board for Integrated Permit Service (BPPT) on behalf of other local boards in the locality. Having secured this primary permit, developers then arrange a location permit and building permits, which can vary according to consumer characteristics. Later, developers can begin marketing and selling houses.

\section{Relationships with larger metropolises}

It is widely assumed that urban development in Cirebon Region is related to deconcentration effects from larger metropolitan areas such as Jakarta and Bandung. It is true that corridors have sporadically grown along the roads to Jakarta and Bandung. The development of key infrastructure such as the Palikanci road and the Kanci-Pejagan toll road - which links Cirebon to Jakarta - has also been found to trigger settlement development. Nevertheless, there is no robust fact to prove that the position of either Jakarta or Bandung influences urban development in Cirebon Region, apart from the improvement in accessibility due to the development of highways and toll roads. The evidence only suggests economic links between these cities in terms of branch office openings in Cirebon Municipality.

Although the development along the corridors towards Jakarta and Bandung does not indicate a vigorous relationship with those larger cities, there is an indication of labour mobility between Cirebon Region and Jakarta and Bandung from the movement of trains and buses to those cities at weekends (ANTARA, 2012a). This suggests that although the rapid and extended urban development in Cirebon Region represents internal triggers, the region is still a part of a larger metropolitan area of effect. We can say that Cirebon remains in the periphery of Greater Jakarta, confirming our view that smaller cities are also part of large global city-regions.

Figure 5. Diagrammatic analysis of urban changes in Cirebon Region 
FIG5.jpg

AROUND HERE

Source: Our elaboration

Overall analysis

A diagrammatic analysis was prepared to present an inclusive examination, see Figure 5. This figure was made by locating all the forces of urban change and indicating the directions of urban development on a map. Overall, our analysis has established that demographic change has led to extensive urban growth, especially in the outer agglomeration of the Municipality. At the same time, housing development has been responsible for most of the development over time. In Cirebon, property development is generally expected to grow further in the near future. Various projects are on the agenda, including a large project by Grage Group to develop the first 'independent city' in Cirebon Region, though this will be still located in the Cirebon Municipality. This project would involve an integrated, high-class residential development with a shopping centre and other amenities, very much like projects in larger metropolitan areas such as Jakarta.

Meanwhile, as also presented above, agricultural and manufacturing activities (home industries) would not be included in the current urban changes for Cirebon. Embankment activities in Kapetakan have created a strip settlement stretching towards the Municipality. Rattan industries in Palimanan have also triggered informal settlements. However, these activities took place years ago. The decline of these sectors, and the gradual increase in the trade and service sectors, also indicates a new kind of dependence of the hinterland on the core.

In this case, Cirebon Municipality plays a very dominant role in the regional system. Although it is said that Cirebon Municipality is only a centre for trade and services, the amount of employment created by these sectors is significant enough to attract people working in the core to adjacent areas in 
search of affordable housing. It is also believed, as interviewees from Cirebon Municipality confirmed, that the day population of the Municipality could double at night. This phenomenon strengthens the argument that people working in the core live in suburbs in District territory, and commute every day. Instead of working, people also come to the core for recreation and shopping, especially at weekends. Generally, in Indonesia people perceive shopping as a kind of recreation, so commercial centres like shopping malls are designed to be comfortable and oriented to leisure recreation.

Furthermore, urban development in agglomerations close to the core may be a result of unsynchronized urban planning and management between those two territories. This lack of harmony reflects poor communication between the two, since the development process, including building permit delivery, is carried out solely by each local government. Unfortunately, infrastructure and basic services are similarly not integrated, and recurrently cause problems for the two territories. The local governments, therefore, tend to have difficulties in responding to challenges in the extended urban region.

\section{CONCLUSION AND FURTHER REMARKS}

This paper has shown that urbanization in Cirebon Region in essence shows classic early-metropolitan development characteristics. Urbanization in Cirebon Region tends to concentrate on the core, thereby creating a concentric pattern; though ribbon development can still be found. Acknowledging Webster (2011), the triggers of urbanization in Cirebon Region are mostly driven by centripetal forces. As illustrated in Figure 5, human mobility and migration are from peripheral to adjacent areas to the core. Population is concentrated in this extended urban area. In line with other cases in Asia (cf. Douglass, 2000; Han, 2010; Webster, 2011), centripetal forces in urbanization in Cirebon also correspond to economic restructuring within the region.

Similar to other cases, residential urbanization seems to be the fundamental aspect of the urbanization of Cirebon. The expansion of settlement is a major factor affecting urbanization. Along with the core, which has been increasingly dominant in commercial activities, urbanization processes 
in general have resulted in concentrations of people and activities in the region leading to the core, thereby creating a new link between the core and emerging small urban settlements. On the other hand, the level of development of the national capital Jakarta is far from that of Cirebon. While Cirebon is still experiencing concentration and expansion of the core, Jakarta seems to be much further developed, where suburbs, satellite cities and independent industrial estates have recently and increasingly been growing. Deconcentration effects from Jakarta also seem too far away to impact on Cirebon, even though there is an indication of labour mobility between them. Therefore, it can be concluded that urban changes in Cirebon correspond to internal processes, and mostly occur at the core.

A further conclusion from this case is that urban change is the result of many factors. Since Cirebon Region does not have a vital economic function at the national level, political restructuring, as embodied in the decentralization policy, seems influential, especially in spatial planning practices which enable local governments to authorize and promote development. While global cities are formed by transnational capital which results in urban growth and spatial concentration, as well as a change in socioeconomic lifestyle (Douglass, 2000; Firman, 2012), for small-medium-sized cities like Cirebon, economic restructuring at the local level is more likely to explain development processes. The shift in sectoral contributions in which trade and service sectors become more dominant has restructured employment shares. A number of jobs in these sectors have attracted people to work in the Municipality. Along with this process, people have attempted to migrate to the core or its adjacent areas to get closer to their workplaces. Furthermore, this generates a mechanism within the land and housing market where people's needs and developers' profit-seeking behaviour are in conflict, resulting in the concentric pattern of settlement in the region.

We also conclude here that settlement development, both formal and informal, is influenced by cultural preferences. High and middle income people prefer locations with better access to the core and basic service quality, while lower income people are forced to live outside those areas. It has been frequently mentioned that in the case of Jakarta and Bandung Metropolitan Areas, concentration around highway corridors connecting the main cities is extensive (cf. Douglass, 2000; Firman, 2009; 
Firman \& Dharmapatni, 1994; McGee, 1991). However, extended urbanization in this smaller city region mainly occurs through concentration around the core.

The case of Cirebon, in any case, carries potential lessons for other intermediate cities or growing smaller cities, particularly those predicted to become metropolitan regions in the future. The kinds of drivers mentioned, therefore, would also come into play in other cases, especially in those where transnational capital is not available. Our findings for Cirebon also imply that accelerated development in smaller cities indicates influence from decentralization policies that enable local governments to more proactively promote economic development. However, as found in this case, while urban expansion is still manageable, it impacts on governance issues. In line with Cohen's 'Small cities, big agenda' (2006), we need to pay careful attention to urban growth in smaller cities, lest the infrastructure and service gaps become more and more overwhelming. A key governance aspect is that local institutional capacity is crucial to dealing with extended urbanization. As Erickcek and McKinney (2006) suggested, this collaboration will also be economically profitable as the tighter the connections between local governments, the more probable are economies of scale in service provision and a focus on regional rather than jurisdictional growth. Unfortunately, similar to other cases in Indonesia, local governments are still striving hard to cope with territoriality issues and local egoism. To date, it has been quite difficult to achieve inter-local government cooperation, especially in basic infrastructure service problems.

\section{FOOTNOTES}

1. According to Firman (2012), small and medium-sized cities in the outer islands are growing more rapidly than those on Java Island. Smaller cities outside Java play a more significant role as the centre of various economic activities. However, his analysis only covers urban localities which are administrative cities (municipalities), whereas the data on urban areas across districts (kabupaten) is not available in demographic-census reports. Urban expansion in Cirebon Region has occurred in the outer area of the Municipality of Cirebon (within the District of Cirebon territory. 
2. Indonesian governance is divided into several tiers of administration. Below the national level are provinces, including the Special Capital Region Jakarta and two special provinces (Aceh and Yogyakarta). Below each province are administrations which can be differentiated as kota (municipality) and kabupaten (district). With regard to autonomic rights, both municipalities and districts have the same authorities to manage their own regions. However, a municipality is generally typified as mostly urbanized and of a relatively higher level of function with respect to its surrounding region, for instance, as an economic activity centre.

3. City-region can be defined as a system consisting of two interrelated components i.e. the city which is the specialist in a set of functions or economic activities, and its surrounding territory which is exclusive to that city (Parr, 2005).

4. The political economy perspective in urban geography (cf. Pacione, 2009) is to elaborate a good insight into the key processes and agents responsible for the production of the built environment of the capitalist city. This approach has exposed the roles of and relationships among various functions of capital influencing urban change.

5. Based on the 2010 Population Result, Firman (2012) shows that there are several 'millionaire cities' which have populations of over one million. Jakarta, Surabaya, Bandung, Medan, Bekasi, Medan, Palembang, Semarang, Tangerang, Depok and Makassar are the millionaire cities.

6. The Board of Community Counseling, Women's Empowerment and Family Planning is responsible for issues of Keluarga Berencana (family planning). In Indonesia, KB has suggested citizens have only two children in each family.

7. Location quotient (LQ) is one of traditional methods for showing basic and non-basic sectors (economic base). LQ describes the employment share of any sector in a region relative to the national share of employment in that sector. Thus, it is the ratio of the regional proportion of employment in a specific sector in the region, relative to the national proportion of employment in the same sector (McCann, 2001). The formula for LQ is: 
8. 'Fatwa permit' is a directional permit delivered to individuals and corporations in terms of land use issues. This permit should be followed up with a 'location permit', which is needed to apply for a building permit (izin mendirikan bangunan) (BPPT Cirebon, 2012).

\section{REFERENCES}

ANTARA. (2010). Angka Kelahiran di Cirebon Rendah, ANTARA Jawa Barat. Retrieved from http://www.antarajawabarat.com/lihat/cetak/24916

ANTARA. (2012a). KA Cirebon Terlambat Tiga Jam, Antara Jawa Barat. Retrieved from http://www.antarajawabarat.com/lihat/cetak/25386

ANTARA. (2012b, 8 January). Wah, industri rotan Cirebon akan dipindahkan ke Sulawesi Barat! , from http://bisnis-jabar.com/index.php/berita/wah-industri-rotan-cirebon-akan-dipindahkan$\underline{\text { ke-sulawesi-barat }}$

Bell, D., \& Jayne, M. (2006). Conceptualizing small cities. In D. Bell \& M. Jayne (Eds.), Small Cities: Urban experience beyond the metropolis: Routledge.

Bell, D., \& Jayne, M. (2009). Small Cities? Towards a Research Agenda. International Journal of Urban and Regional Research, 33(3), 683-699. doi: 10.1111/j.1468-2427.2009.00886.x

BPPT Cirebon. (2012). Pelayanan Perizinan Retrieved November 25, from http://bppt.cirebonkab.go.id/layanan/

Central Statistics Agency. (1990). Monograph of Village and Kelurahan 1990.

Central Statistics Agency. (1992a). National Social-Economic Survey 1992. Province of West Java.

Central Statistics Agency. (1992b). Statistik Indonesia 1992. 
Central Statistics Agency. (1996). Gross Regional Domestic Product 1994-1996. Municipality of Cirebon.

Central Statistics Agency. (1999). Gross Regional Domestic Product 1994-1999. District of Cirebon.

Central Statistics Agency. (2000). Monograph of Village and Kelurahan 2000.

Central Statistics Agency. (2001). Gross Regional Domestic Product 1997-2001. Municipality of Cirebon.

Central Statistics Agency. (2004). Gross Regional Domestic Product 2004-2007. Municipality of Cirebon.

Central Statistics Agency. (2006). Monograph of Village and Kelurahan 2006.

Central Statistics Agency. (2008). Gross Regional Domestic Product 2000-2008. District of Cirebon.

Central Statistics Agency. (2009a). Forming Social Economic Data (Suseda) 2009 West Java. West Java Province.

Central Statistics Agency. (2009b). National Labor Force Survey (Sakernas) 2009.

Cirebon Pos Kota. (2011, July 30). Bisnis Properti di Cirebon Menjanjikan, Newspaper article.

Cohen, B. (2004). Urban Growth in Developing Countries: A Review of Current Trends and a Caution Regarding Existing Forecasts. World Development, 32(1), 23-51. doi: 10.1016/j.worlddev.2003.04.008

Cohen, B. (2006). Urbanization in developing countries: Current trends, future projections, and key challenges for sustainability. Technology in Society, 28(1-2), 63-80. doi: 10.1016/j.techsoc.2005.10.005

Davis, J. C., \& Henderson, J. V. (2003). Evidence on the political economy of the urbanization process. Journal of Urban Economics, 53(1), 98-125. doi: 10.1016/s0094-1190(02)00504-1 
Dix, G. (1986). Small cities in the world system. Habitat International, 10(1-2), 273-282. doi: http://dx.doi.org/10.1016/0197-3975(86)90030-5

Douglass, M. (2000). Mega-urban Regions and World City Formation: Globalisation, the Economic Crisis and Urban Policy Issues in Pacific Asia. Urban Studies, 37(12), 2315-2335. doi: $10.1080 / 00420980020002823$

Erickcek, G. A., \& McKinney, H. (2006). “Small Cities Blues:” Looking for Growth Factors in Small and Medium-Sized Cities. Economic Development Quarterly, 20(3), 232-258. doi: $10.1177 / 0891242406290377$

Firman, T. (2009). The continuity and change in mega-urbanization in Indonesia: A survey of Jakarta-Bandung Region (JBR) development. Habitat International, 33(4), 327-339. doi: http://dx.doi.org/10.1016/j.habitatint.2008.08.005

Firman, T. (2012). Demographic Patterns of Indonesia's Urbanization, 2000-2010: Continuity and Change at the Macro Level. Paper presented at the Planocosmo International Conference, Institute of Technology, Bandung, November, 8-9.

Firman, T., \& Dharmapatni, I. A. I. (1994). The challenges to sustainable development in Jakarta metropolitan region. Habitat International, 18(3), 79-94. doi: http://dx.doi.org/10.1016/0197$\underline{3975(94) 90006-X}$

Geyer, H. S. (1993). A Theoretical Foundation for the Concept of Differential Urbanization. International Regional Science Review, 15(2), 157-177.

Goldblum, C., \& Wong, T.-C. (2000). Growth, crisis and spatial change: a study of haphazard urbanisation in Jakarta, Indonesia. Land Use Policy, 17(1), 29-37. doi: 10.1016/s0264$8377(99) 00043-5$

Han, S. S. (2010). Urban expansion in contemporary China: What can we learn from a small town? Land Use Policy, 27(3), 780-787. doi: 10.1016/j.landusepol.2009.10.010 
Hinderink, J., \& Titus, M. J. (1988). Paradigms of Regional Development and the Role of Small Centres. Development and Change, 19(3), 401-423. doi: 10.1111/j.1467-7660.1988.tb00308.x

Hinderink, J., \& Titus, M. J. (2002). Small Towns and Regional Development: Major Findings and Policy Implications from Comparative Research. Urban Studies, 39(3), 379-391. doi: $10.1080 / 00420980220112748$

Kompas. (2008, March 12). Properti di Cirebon Terkendala Daya Beli, Newspaper article.

Kompas. (2010, April 6). Kota Cirebon Makin Sesak, Newspaper article.

McCann, P. (2001). Urban and Regional Economics: Oxford University Press.

McGee, T. G. (1991). The Emergence of Desakota Regions in Asia: Expanding a Hypothesis. In N. Ginsburg, B. Koppel \& T. G. McGee (Eds.), The Extended Metropolis Settlement Transition in Asia. Honolulu: University of Hawaaii Press.

Ministry of Trade. (2011). Press conference 30 November 2011 "Pemerintah Keluarkan Larangan Ekspor Bahan Baku Rotan". Retrieved from http://www.id.indonesia.nl/content/view/1787/183/

National Coordinating Agency for Surveys and Mapping (Cartographer). (1994). Peta Rupa Bumi Indonesia 1994.

National Coordinating Agency for Surveys and Mapping (Cartographer). (1997). Peta Rupa Bumi Indonesia 1997.

National Coordinating Agency for Surveys and Mapping (Cartographer). (2001). Peta Rupa Bumi Indonesia 2001.

National Coordinating Agency for Surveys and Mapping (Cartographer). (2005). Peta Rupa Bumi Indonesia 2005. 
National Coordinating Agency for Surveys and Mapping (Cartographer). (2009). Peta Rupa Bumi Indonesia 2009.

Pacione, M. (2009). Urban Geography A Global Perspective (3rd ed.). London and New York: Routledge.

Parr, J. (2005). Perspectives on the city-region. Regional Studies, 39(5), 555-566. doi: $10.1080 / 00343400500151798$

Prabatmodjo, H. (1993). Peran Kota Kecil dalam Konteks Wilayah Mega Urban (The Role of Small Cities in the Context of Mega Urban, in bahasa Indonesia). Jurnal Perencanaan Wilayah dan Kota, October 1993.

Real Estat Indonesia West Java. (2012). List of Projects by REI Members in West Java.

Law 26 (2007) on Spatial Planning (2007).

Government Regulation 26 (2008) on National Spatial Plan (2008).

Rondinelli, D. A. (1983). Towns and Small Cities in Developing Countries. Geographical Review, 73(4), 379-395.

United Nations. (2012). World Urbanization Prospects: the 2011 Revision: Population Division, Department for Economic and Social Affairs.

Webster, D. (2011). The Future of Peri-Urbanization in Developing Countries: Colliding Transnational and Local Forces. Unpublished paper.

Provincial Regulation 22 (2010) on Spatial Plan of West Java Province 2009-2029 (2010).

Zhou, G. S. (1991). Urbanisation in China: The rapid growth of small cities and rational regrouping of cities of different sizes. Habitat International, 15(3), 143-147. doi: http://dx.doi.org/10.1016/0197-3975(91)90038-M 
TABLE 1 SHARES OF URBAN AGGLOMERATION IN CIREBON REGION, 1990-2006

\begin{tabular}{|c|c|c|c|c|c|c|c|}
\hline \multirow[b]{2}{*}{ No. } & \multirow{2}{*}{$\begin{array}{l}\text { Type of urban } \\
\text { agglomerations }\end{array}$} & \multicolumn{2}{|c|}{1990} & \multicolumn{2}{|c|}{2000} & \multicolumn{2}{|c|}{2006} \\
\hline & & $\begin{array}{c}\text { Urban } \\
\text { population }\end{array}$ & Share & $\begin{array}{c}\text { Urban } \\
\text { population }\end{array}$ & Share & $\begin{array}{c}\text { Urban } \\
\text { population }\end{array}$ & Share \\
\hline 1 & Core (Municipality) & 213,063 & $11 \%$ & 242,149 & $12 \%$ & 249,877 & $10.9 \%$ \\
\hline 2 & Adjacent to the core & 186,960 & $10 \%$ & 218,959 & $10 \%$ & 405,878 & $17.7 \%$ \\
\hline 3 & $\begin{array}{l}\text { Stripping along } \\
\text { regional road to } \\
\text { Jakarta-Bandung }\end{array}$ & 187,410 & $10 \%$ & 202,350 & $10 \%$ & 230,504 & $10.1 \%$ \\
\hline 4 & $\begin{array}{l}\text { Stripping along } \\
\text { regional road to } \\
\text { Central Java }\end{array}$ & NA & NA & NA & NA & 249,749 & $10.9 \%$ \\
\hline 5 & Scattered & 218,298 & $12 \%$ & 229,373 & $11 \%$ & 200,774 & $8.8 \%$ \\
\hline \multicolumn{2}{|c|}{$\begin{array}{l}\text { Urban population in } \\
\text { Cirebon Region }\end{array}$} & 805,731 & $43 \%$ & 892,831 & $43 \%$ & $1,336,782$ & $58.4 \%$ \\
\hline \multicolumn{2}{|c|}{$\begin{array}{l}\text { Total Population in Cirebon } \\
\text { Region }\end{array}$} & \multicolumn{2}{|c|}{$1,872,062$} & \multicolumn{2}{|c|}{$2,095,276$} & \multicolumn{2}{|c|}{$2,287,798$} \\
\hline
\end{tabular}


TABLE 2 LOCATION QUOTIENTS FOR THE DISTRICT AND THE MUNICIPALITY IN 1992

AND 2007

\begin{tabular}{|c|c|c|c|c|c|c|}
\hline \multirow{2}{*}{ No. } & \multirow{2}{*}{ Sectors } & \multicolumn{2}{|c|}{1992} & \multicolumn{2}{|c|}{2007} & \multirow{2}{*}{$\begin{array}{l}\text { Annual Growth } \\
\text { in Share of } \\
\text { National } \\
\text { Employment } \\
\text { (1992-2007) }\end{array}$} \\
\hline & & District & Municipality & District & Municipality & \\
\hline 1 & Agriculture & 0.7275 & 0.0779 & 0.5181 & 0.1166 & $-0.15 \%$ \\
\hline 2 & Mining & 0.8657 & 1.7509 & 0.0746 & 0.6707 & $4.35 \%$ \\
\hline 3 & Manufacturing & 1.0916 & 0.9225 & 1.1185 & 0.4530 & $2.73 \%$ \\
\hline 4 & $\begin{array}{l}\text { Electricity, gas } \\
\text { and water }\end{array}$ & 0.3784 & 4.8520 & 0.8489 & 8.3918 & $0.50 \%$ \\
\hline 5 & Construction & 1.4633 & 2.8717 & 1.5969 & 1.1176 & $5.03 \%$ \\
\hline 6 & Trade & 1.7458 & 2.4703 & 1.5406 & 2.0252 & $3.80 \%$ \\
\hline 7 & Transportation & 2.0822 & 2.4487 & 1.1698 & 1.5001 & $5.76 \%$ \\
\hline 8 & Finance & 0.3631 & 4.1133 & 0.1609 & 2.5732 & $6.12 \%$ \\
\hline 9 & Services & 0.8646 & 2.1063 & 1.2366 & 2.1977 & $1.29 \%$ \\
\hline
\end{tabular}


TABLE 3 EXAMPLES OF LARGE HOUSING DEVELOPMENT PROJECTS IN CIREBON

REGION 2007-2012

\begin{tabular}{|l|l|l|l|l|l|l|}
\hline No. & \multicolumn{1}{|c|}{ Name of project } & Area (ha) & $\begin{array}{c}\text { Target } \\
\text { group }\end{array}$ & $\begin{array}{c}\text { Year } \\
\text { project } \\
\text { started }\end{array}$ & \multicolumn{2}{|c|}{ Location } \\
\hline 1 & Cirebon Raya & 25.05 & Low & 2007 & $\begin{array}{l}\text { Cirebon Utara and } \\
\text { Cirebon Barat }\end{array}$ & District \\
\hline 2 & Griya Lobunta Lestari & 23.2425 & Low & 2011 & Mundu & Municipality \\
\hline 3 & Taman Tukmudal Indah & 22 & Low & 2009 & Sumber & District \\
\hline 4 & Taman Kalijaga Permai & 20 & Middle-high & 2010 & Harjamukti & Municipality \\
\hline 5 & Gerbang Permai Pamengkang & 18.497 & Low & 2009 & Mundu & District \\
\hline 6 & Griya Sunyaragi Permai & 16.5 & Middle-high & 2008 & Kesambi & Municipality \\
\hline 7 & Bumi Cirebon Adipura & 16.2 & Low & 2008 & Mundu & District \\
\hline 8 & The Gardens & 11 & Middle & 2011 & Talun & District \\
\hline 9 & Bumi Asri Pamijahan & 10 & Low & 2009 & Pamijahan & District \\
\hline 10 & Bumi Babakan Indah & 10 & Low & 2009 & Babakan & District \\
\hline
\end{tabular}


igure 1

Click here to download high resolution image

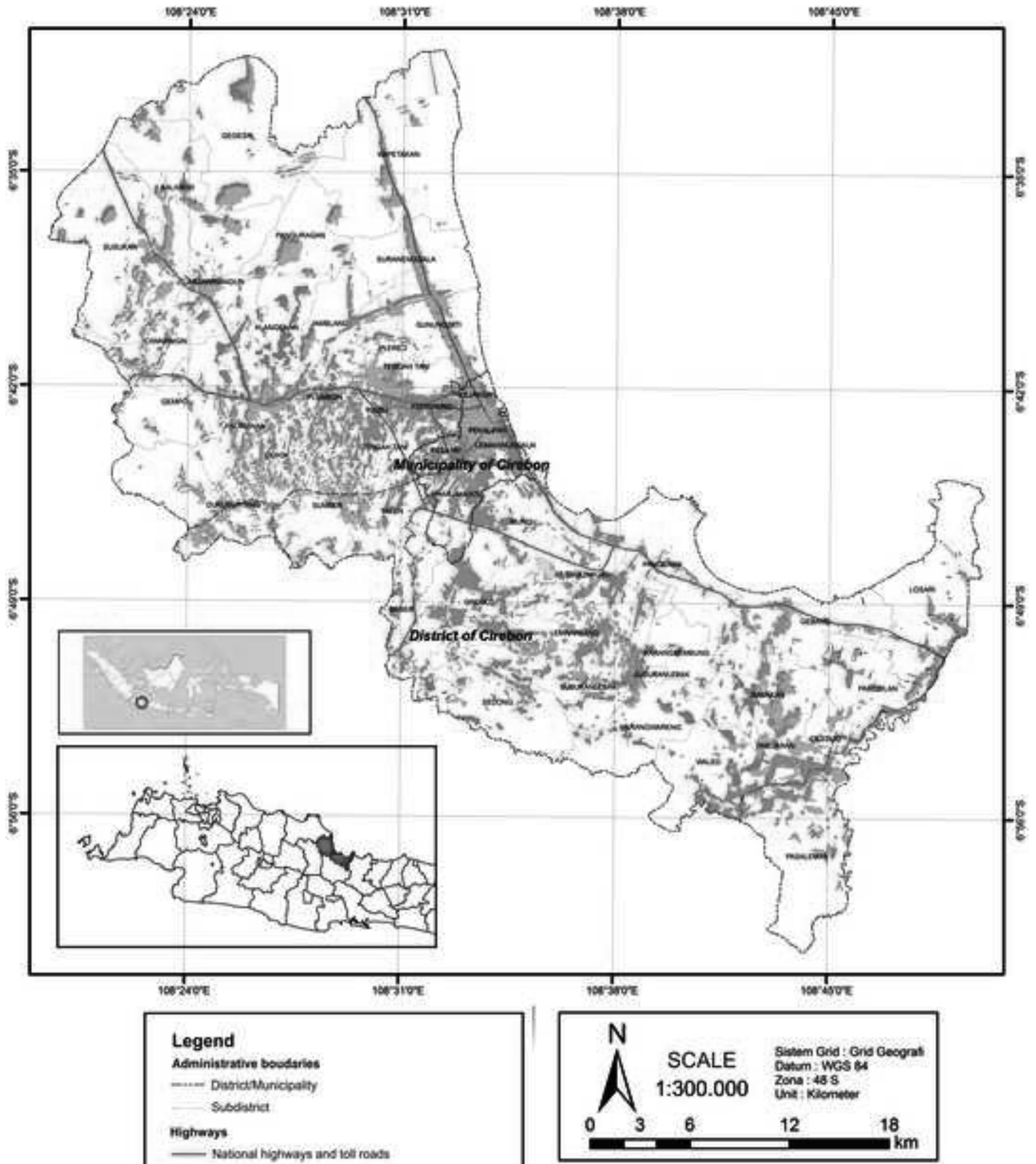

Builtup ares

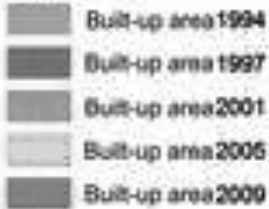


Figure 2

FIGURE 2 PERCENTAGES OF GRDP IN THE CIREBON DISTRICT 1995-2005

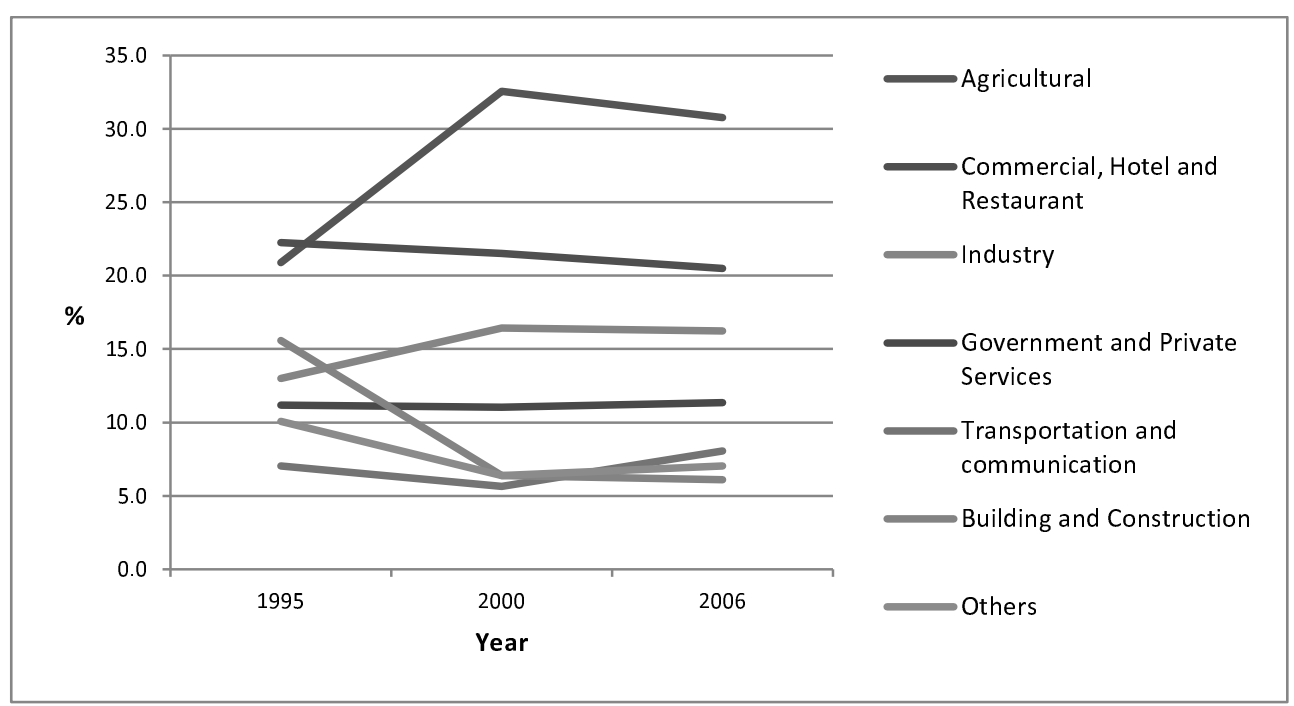


Figure 3

FIGURE 3 PERCENTAGES OF GRDP IN THE CIREBON MUNICIPALITY 1995-2005

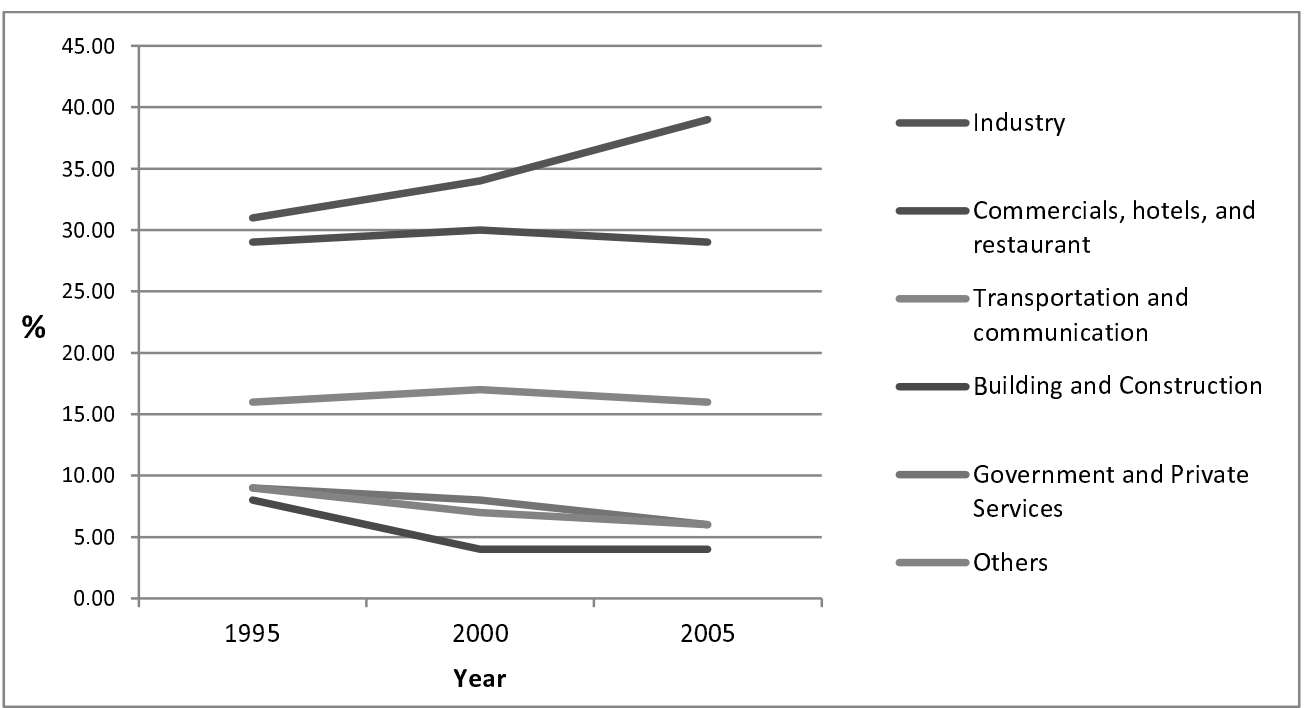


FIGURE 4 DEVELOPMENTS IN THE NUMBER OF PROJECTS AND THEIR AREA (HA) IN CIREBON REGION

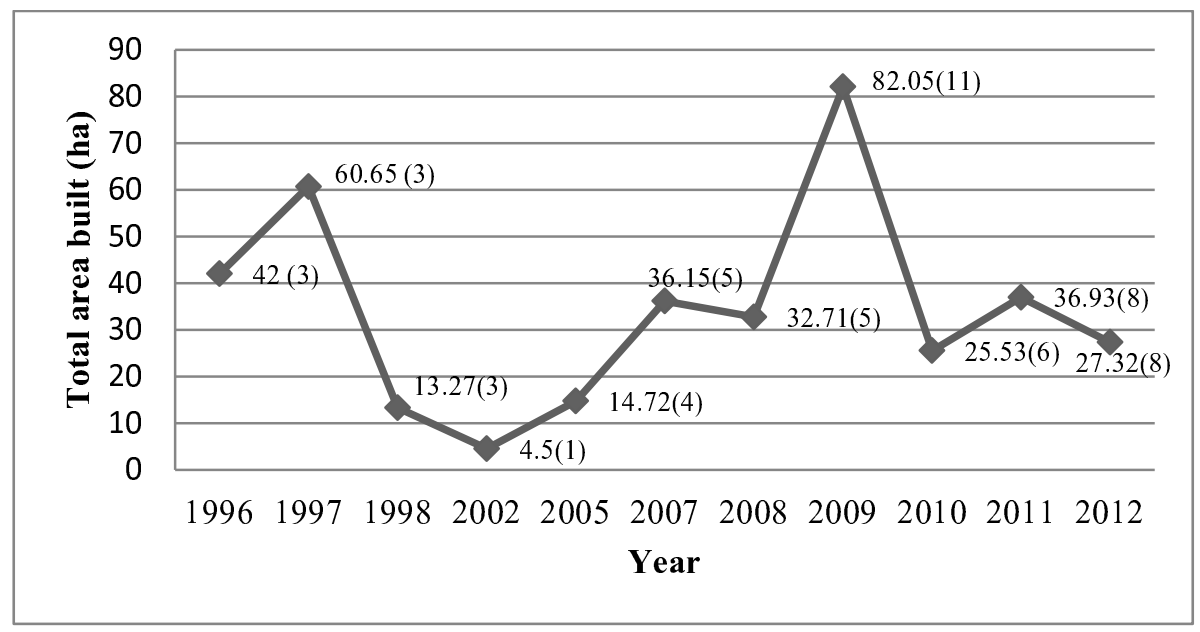




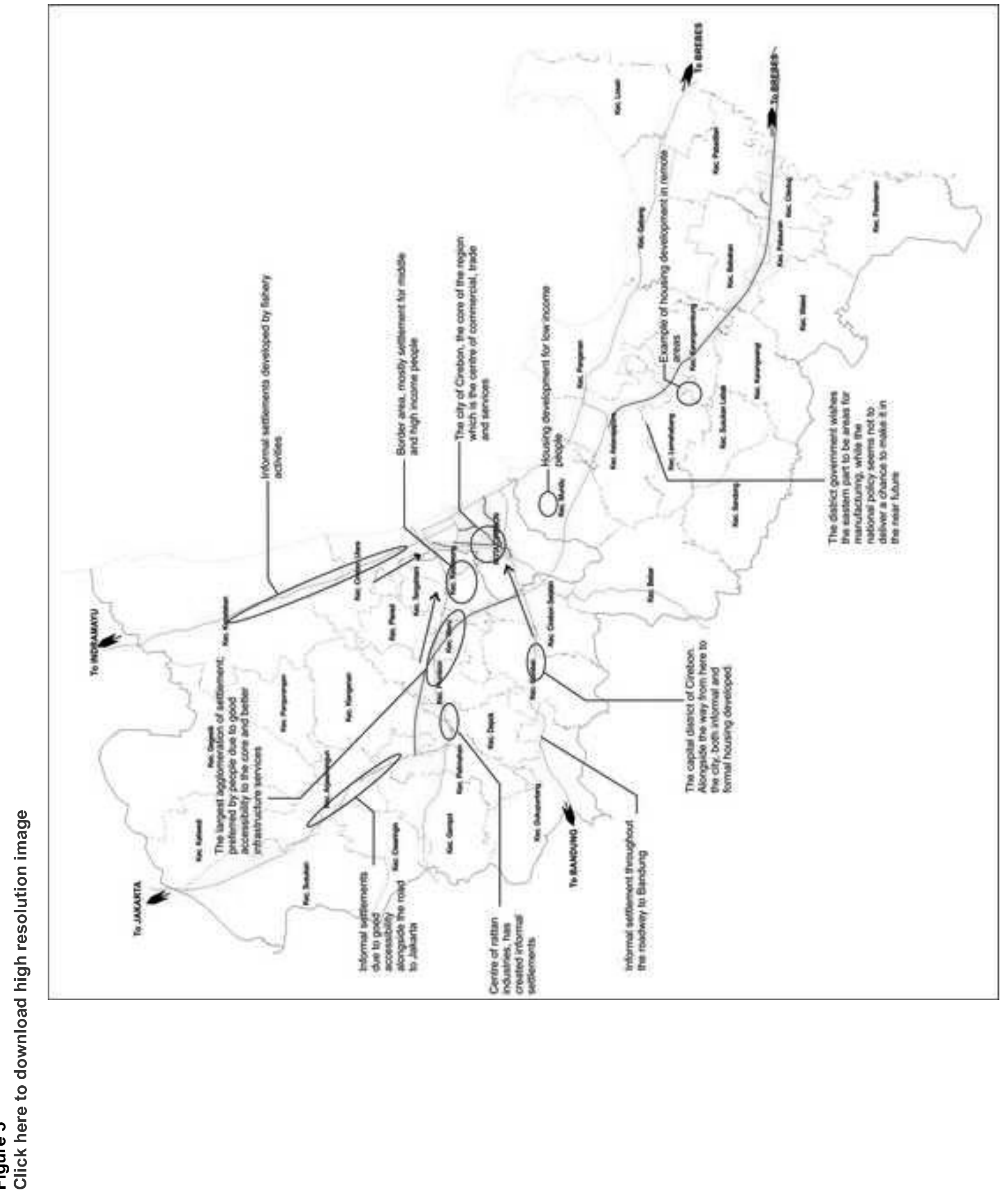

